NBSIR $73-416$

\title{
Report on Meeting of ISO/TC 6/SC 5 Testing Methods and Quality Specifications for Pulp
}

William K. Wilson.* John H. Schulz.** C. Edwin Brandon.*** Joseph L. Borstelmann *****

*National Bureau of Standards

** Continental Can Company. Inc.

***Miami University, Oxford. Ohio

**** Technical Association of the Pulp and Paper industry

November 16. 1973

Meeting Held in

Madrid. Spain

November 2-8. 1973

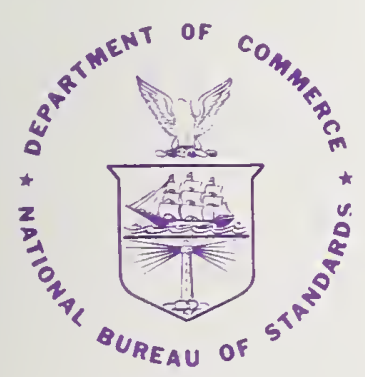

U. S. DEPARTMENT OF COMMERCE, Frederick B. Dent. Secretary 


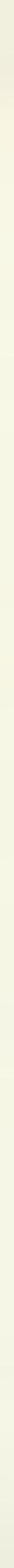




\section{REPORT ON MEETING OF ISO/TC 6/SC 5 \\ TESTING METHODS AND QUALITY \\ SPECIFICATIONS FOR PULP}

William K. Wilson,* John H. Schulz,** C. Edwin Brandon, ${ }^{* * *}$ Joseph L. Borstelmann, ${ }^{* * * *}$

*National Bureau of Standards

**Continental Can Company, Inc.

***Miami University, Oxford, Ohio

****Technical Association of the Pulp and Paper Industry

November 16,1973

Meeting Held in

Madrid, Spain

November 2-8, 1973 

1. StAtement OF Results ................. . 1

2. BACKGROUND . . . . . . . . . . . . . . 2

3. GENERAL IMPRESSIONS •. . . . . . . . . . 6

4. RECOMMENDATIONS . . . . . . . . . . . . . 8

5. REPORT ON MEETING OF WORKING GROUP 1, SALEABLE MASS OF PULP . . . . . . . . . . . . 10

5.1 Agenda of Meeting . . . . . . . . . . 10

5.2 Secretariat Memorandum of September 1973 . . . Il

5.3 Discussion at Working Group Meeting . . . . 12

6. REPORT ON MEETING OF WORKING GROUP 6 , AQUEOUS EXTRACTS . . . . . . . . . . . . . 14

6.1 Agenda of Meeting . . . . . . . . . . . 14

6.2 Secretariat Memorandum of September 1973 . . . 16

6.3 Discussion at Working Group Meeting . . . . . 17

7. FEPORT ON MEETING OF WORKING GROUP 8,

PREPARATION OF LABORATORY SHEETS FOR PHYSICAL

TESTING •. . . . . . . . . . . . . . . 19

7. 1 Agenda of Meeting . . . . . . . . . . 19

7.2 Secretariat Memorandum of September 1973... 20

7.3 Discussion at Working Group Meeting . . . . . 21

8. REPORT ON MEETING OF WORKING GROUP 1 OF SC 2,

OPTICAL PROPERTIES OF PAPER, BOARD, AND PULP • • • 23

8.1 Agenda of Meeting . . . . . . . . . . 23

8.2 Secretariat Memorandum of September 1973 . . 24

8.3 Discussion at Working Group Meeting . . . . 25

9. REPORT ON TECHNICAL SESSION OF SC 5 . . . . . . 27

9.1 Opening of the Meeting. . . . . . . . . 27

9.2 Saleable Mass, in Lots, of Pulp . . . . . . 28

9.3 Disintegration for Tests on Unbeaten Pulps • . 29 
$\underline{\text { Page }}$

9.4 Laboratory Beating of Pulp . . . . . . 30

9.5 Preparation of Laboratory Sheets . . . . 31

9.6 Testing of Physical Properties of Pulp • . 33

9.7 Viscosity of Pulp. . . . . . . . . . 34

9.8 Aqueous Extracts of Paper and Pulp . . . . 35

9.9 Dirt and Shives in Pulp . . . . . . . . 36

9.10 Determination of Total Sulphur Content.. . 37

9.11 Optical Properties of Pulp..... . . . 38

9.12 Revision of ISO Recommendations . . . . . 39

9.13 Canadian Standard Freeness ..... . . . . 40

9.14 Schopper Riegler Freeness . . . . . . . 41

9.15 Accelerated Aging of Pulp ....... . 42

10. DRAFT RESOLUTIONS ............. 43

11. PROGRAM FOR FUTURE WORK . . . . . . . . . . 49

12. TIME AND PLACE OF NEXT MEETING . . . . . . . 50

13. SPLCIAL EVENTS . . . . . . . . . . 51

14. APPENIIX . . . . . . . . . . 52

14.1 Agenda of Meeting of SC 5 . . . . . . 52

14.2 Delegates to Meeting of SC 5...... 55

14.3 Delegates to Eighth Meeting of WG 1,

Saleable Mass of Pulp . . . . . . . 56

14.4 Delegates to Second Meeting of WG 6,

14.5 Delegates to Meeting of WG 8,
Preparation of Laboratory Sheets ...... 58

14.6 Delegates to Meeting of WG 1 of SC 2,

14.7 List of Working Groups .......... 60

14.8 ISO Recommendations From SC 5 . . . . . 62

$14.96 / 5 \mathrm{~N} 416$, Comparison of Methods for
Sulphate Ion Determination . . . . 63 


\section{STATEMENT OF RESULTS ${ }^{1}$}

Over 30 delegates from Canada, Finland, France, Germany, Norway, Poland, Portugal, Spain, Sweden, United Kingdom, and the USA attended a meeting in Madrid of the subcommittee of the International Organization for Standardization (ISO) dealing with testing methods and quality spacifications for pulps used for papermaking and other purposes; an observer from the customs cooperation council was also present.

Methods were agreed upon for the determination of saleable mass of flash-dfied pulps, for disintegration of pulp, laboratory beating of pulp, preparation of laboratory sheets, and measurement of ISO brightness of pulps.

It was also agreed to revise current IsO Recommendations For determination of saleable mass of pulp in lots ( $R$ 801), determination of dry matter content ( $R$ 638), and calcium, copper, iron, and manganese content of pulp ( $\mathrm{R} 777,778,779$, and 1830 ).

Many other items were discussed. Plans were made to continue studies of methods for the determination of viscosity, aqueous extraction, dirt and shives, total sulphur content, saleable mass of unitized lots of pulp, statistical evaluation of number of sample bales, preparation of laboratory sheets by the Rapid-Kothen method, and fiber classification and drainability.

The Subcommittee met from 6 th to 8 th November 1973 inclusive, under the chairmanship of Professor Waldemar Jensen (Finland).

${ }^{1}$ Statement prepared for the press by the Editing Committee, with minor changes. 


\section{BACKGROUND}

The International Organization for Standardization was established in 1947 for the development of standard methods of evaluation and specifications that would be useful in international trade. TC 6, Paper, was organized in 1947, and France has held the secretariat continuously since that time. SC 5, Testing Methods and Quality Specifications for Pulp, was organized in 1961 and the secretariat was entrusted to Finland. Dr. Waldemar Jensen, Managing Director of the Finnish Pulp and Paper Research Institute, has assumed the responsibility for this work. His Institute is responsible for five of the eight working groups, and for those efforts for which working groups do not exist.

The first meeting of SC 5 was held in Helsinki in 1961, the second in Paris in 1962, the third in Rome in 1963, the fourth in Stockholm in 1965, the fifth in Montreal, Canada in 1967, the sixth in Oslo, Norway in 1969, the seventh in London, England in 1970, and the eighth in Berlin in 1972. The U.S. did not participate in the first two meetings, but was represented by one delegate in Rome, by two delegates in Stockholm, by seven delegates in Montreal, by three delezates in Oslo, and by four in London, and by three in Berlin*.

The following countries are participating members of $\mathrm{SC} 5$ ( $\mathrm{P}$ members):

$\begin{array}{lll}\text { Australia } & \text { France } & \text { Portugal } \\ \text { Belgium } & \text { Germany } & \text { Rumania } \\ \text { Bulgaria } & \text { Israel } & \text { Spain } \\ \text { Canada } & \text { Italy } & \text { Sweden } \\ \text { Colombia } & \text { Netherlands } & \text { United Arab Republic } \\ \text { Czechoslovakia } & \text { New Zealand } & \text { United Kingdom } \\ \text { Ethiopia } & \text { Norway } & \text { USA } \\ \text { Finland (Secretariat) } & \text { Poland } & \text { USSR }\end{array}$

Participating members may contribute to the work of the Subcommittee and are entitled to vote on documents as they are processed through channels.

*A special meeting of SC 5 was held in Helsinki in August 1968 to discuss questions relating to the laboratory beating of pulp. 
A country with observer status receives all communications but cannot vote. The following countries are listed as observer members (O members):

$\begin{array}{lll}\text { Austria } & \text { India } & \text { Republic of South Africa } \\ \text { Cuba } & \text { Japan } & \text { Switzerland } \\ \text { Denmark } & \text { Peru } & \text { Yugoslavia }\end{array}$

Member countries operate through their national standardizing organizations. In the U.S. this is the American National Standards Institute. Members of working groups may communicate directly with each other.

Liaison organizations with SC 5 include the following:

1. Customs Cooperation Council

2. Secretariat of TC $6 / \mathrm{SC} 2$, Test Methods for Paper and Paperboard

3. Secretariat of TC 38, Textiles, SC 16, Chemical Testing.

4. IEC (International Electrotechnical Commission)/ rC 15, Insulating Materials

Methods and specifications are developed in SC 5 specifically for use in the buying and selling of pulps. Therefore, purely emfirical methods may be very useful, but the tendency is to keep the methods as close to current scientific developments as possible. Process control methods are not considered.

Most of the effort on standards, both national and international, in Europe is through research institutes which may also act as standardizing bodies. Research on materials, the development of test methods, the writing of specifications, and the promulgation of standards are all within one organization. Thus, it is possible to make the most of whatever funds are available. Funds usually come from both industry and government, as in Sweden. The Norwegian Pulp and Paper Research Institute is supported entirely by industry.

The European members of SC 5 have contributed a large part of the effort. The Scandinavian countries in particular are strong in SC 5, and are responsible for all of the eight working groups. The U.S. participates in all of the working groups. 
There is no accepted procedure for determining the relative level of effort that might be expected of a country participating in the work of ISO/TC 6/SC 5. As ISO test methods are designed to assist in the buying and selling of pulp, the sum of a country's imports and exports as a percentage of the total imports and exports of the countries participating in SC 5 might be used as a rough guide. These data for 1972 are given in Table l. According to this formula, the U.S. should be contributing about 20 percent of the total effort of SC 5 .

An organization called the Commission European de Normalisation (CEN) has been in existence for many years, but has not been particularly active until the past two years. CEN is the European response to ISO. It is a standardizing organization for the European Economic Community (EEC) and the European Free Trade Association (EFTA). Most European countries that do not belong to the EEC belong to EFTA.

CEN standards are obligatory on the EEC and EFTA countries six months after adoption. 
Table 1. Pulp imports and exports for: $1972^{1}$ of the countries participating in ISO/TC $6 / \mathrm{SC} 5$.

\begin{tabular}{|c|c|c|c|c|}
\hline Australia & 273 & 11 & .284 & 1.0 \\
\hline Belgium & 358 & 126 & 484 & 1.7 \\
\hline Bulgaria & 80 & 16 & 96 & .3 \\
\hline Canada & 96 & 5,536 & 5,532 & 20.2 \\
\hline Colombia & 58 & 5 & 63 & .2 \\
\hline Czechoslovakia & 87 & 17 & 104 & .4 \\
\hline Ethiopia & 4 & 0 & 4 & .1 \\
\hline Finland & 4 & 1,611 & 1,615 & 5.8 \\
\hline France & 1,333 & 150 & 1,483 & 5.3 \\
\hline Germany & 1,720 & 100 & 1,820 & 6.5 \\
\hline Israel & 55 & -- & 55 & .2 \\
\hline Italy & 1,245 & 2 & 1,247 & 4.5 \\
\hline Netherlands & 621 & 13 & 634 & 2.3 \\
\hline New Zealand & 14 & 110 & 124 & .4 \\
\hline Norway & 210 & 785 & 995 & 3.6 \\
\hline Poland & 195 & 12 & 207 & .7 \\
\hline Portugal & 19 & 380 & 399 & 1.4 \\
\hline Rumania & 66 & 41 & 107 & .4 \\
\hline Spain & 340 & 16 & 356 & 1.3 \\
\hline Sweden & 37 & 3,741 & 3,778 & 13.5 \\
\hline United Arab Republic & 35 & -- & 35 & .1 \\
\hline UK & 2,190 & 3 & 2,193 & 7.9 \\
\hline USA & 3,386 & 2,029 & 5,415 & 19.4 \\
\hline USSR & 265 & 467 & 732 & 2.6 \\
\hline Grand Total & & & 27,862 & \\
\hline
\end{tabular}

${ }^{1}$ Pulp and Paper International, Review Number, July 1973. 


\section{GENERAL IMPRESSIONS}

The meetings are very formal. English is the principal language, but translations are almost alway: made into French. Most of the delegates are operating outside of their native tongue. It is desirable for the U.S. delegates to be deliberate in their speech and to keep the use of idions to a minimum.

Rapport between the U.S. delegates and the other delegates appears to have become much better with eaci meeting. This has been possible for two reasons: (1) the delegations from most countries are remarkably constant from year to year, and (2) as the U.S. shows more and more interest in the work of SC 5, U.S. delegates are recognized as members of the group.

The experience of this meeting confirms the experience at the Montreal, Oslo, and London meetings of the desirability of sending a delegation of several members. Two or more working groups may meet simultaneously. As it is impossible for one person to be expert in all technical areas, it is desirable to ask that each delegate be responsible for specific items on the agenda. This worked very well in Montreal, Oslo, London, and Berlin, and the U.S. had at least one knowledgeable delegate in each technical area.

Delegates should be fully prepared on the subjects for which they are responsible. This should include a knowledge of what is in the literature, of what the working group is doing, including all documents from the secretariat, need for snecific methods, and economic implications.

It is unnecessary for delegates to be able to speak or understand French, but even a mediocre command of another language (French, German, Italian, Spanish) can be helpful as a generator of goodwill.

When traveling to Europe, delegates should allow at least one full day for the body to adjust to the "compression of time." A few hours rest after checking into the hotel usually is sufficient.

Technical progress is slow, but the goodwill generated from sincere cooperation on an international level is of great value. However, when international committees operate in the same way as national standardizing committees, the speed of action is much less. Unless some mechanism can be 
found to accelerate ISO work, the effectiveness of the organization is likely to deteriorate. It has been pointed out that (1) we must achieve standards in half the time if our efforts are to be useful; (2) a good standard is better than a best standard if it is completed in time to be used; (3) the lifetimes of many products are shorter than the time required to develop an ISO standard;

(4) the Central organization must exercise more stringent control over the technical committees; (5) Iso must rethink its objectives and priorities or it will become obsolete. ${ }^{1}$

The Commission European de Normalisation, mentioned in section 2, has the capacity to be a real factor in trade in Europe. Therefore, it would appear that U.S. involvement in Iso is of vital importance.

${ }^{1}$ Address by R. L. Hennessy, Executive Director, Standards Council of Canada, before an ISO session, The World Going Metric--Impact on International standardization, washington, D.C., September 12, 1973. 


\section{RECOMMENDATIONS}

1. The U.S. should continue to consider the work of ISO/ TC 6/SC 5 important and to participate actively in the work of this subcommittee and of its working groups.

2. In addition to participating actively in working groups, the U.S. should assume responsibility for some, as new ones are formed. This participation demands work in the laboratory. Contributing to a disclussion at a meeting, or responding to a questionnaife, cannot be considered as active participation.

3. Delegates should be sent to all meetings of SC 5 and to meetings of the working groups. Progress usually is best achieved through personal contact as the mission of a working group or indication of need for a method can change drastically during discussion at a meeting.

4. Continuity of effort and continuity of delegate participation is important. Within the experience of the U.S. delegates ( 7 meetings), a hard core of delegates familiar with the history and technology of the work, has attended from most of the countries.

5. If possible, comments on methods should be presented in writing before meetings are held, and a delegate should be present at the meeting to present the. comments in person.

6. In order to implement Recommendation No. 5, ASTM and TAPPI methods that are pertinent to the work of SC 5 should be examined on a continuing basis and suitable methods submitted to ANSI Committee P3.

7. The U.S. should propose methods to the working groups as early as possible in the development of the work. These should be ANSI standards, although TAPPI or ASTM standards would have adequate standing.

8. It is very important that methods be submitted through the cognizant committeeman or, still better, through the working group representative. If a proposed method is outside the framework of an established working group, need for the method should be well documented and suggested as an item on the program for future work. 
9. In view of the increasing activity of the Commission European de Normalisation, the U.S. Cominittee for ISO/ TC 6 should make every effort to accelerate participation in ISO. 
5. REPORT ON MEETING OF WORKING GROUP 1 , SALEABLE MASS OF PULP

\subsection{Igenda of Meeting}

The eighth meeting of ISO/TC $6 / \mathrm{SC} 5 /$ WG 1 was held at Instituto Nacional de Investigaciones Agrarias, Avenida de Puerta Hierro, $s / n$, Madr $\downarrow d$, Spain, on Monday, 5 th November 1973, at 9 a.m.

1. Opening of meeting

2. Election of chairman

3. Approval of draft agenda

4. Statistical evaluation of number of sample bales ciocuments: ISO/TC 6/SC 5/WG 1 (Secretariat-17) 46 ISO/TC 6/SC 5/WG 1 (Finland-4) 49 ISO/TC $6 / \mathrm{SC} 5 /$ WG 1 (USA-3) 52 . ISO/TC 6/SC 5/WG 1 (Secretariat-19) 53

5. Determination of saleable mass in lots of flash dried pulp document: ISO/TC 6/SC 5 (Secretariat-192) 410

6. Sampling of unitized bales for moisture testing document: ISO/TC 6/SC 5/WG 1 (Secretariat-21) 55

7. Revision of ISO Recommendation $R 801$ document: ISO/TC 6/SC 5/WG 1 (Secretariat-22) 56

8. Program of future work

9. Other questions

10. Closing of meeting 
5.2 Secretariat Memorandum of September 1973

(Secretariat-193) 411

Statistical evaluation of number of sample bales

The principles of the method for the evaluation of the number of sample bales have been discussed on several occasions and based on these discussions, document 6/5/I N 46 was drafted and submitted for comments in 1972. Later two opposite documents concerning the number of degrees of freedom to be used for the calculation of the confidence limits have been presented by Finland and the USA.

In document $6 / 5 / 1 \mathrm{~N} 53$ the Secretariat proposed that Technical Committee 69, Application of Statistical Methods, be consulted. This proposal has been seconded by France and Norway and no objections have been made.

Determination of saleable mass in lots of flash dried pulp

At the Berlin meeting of ISO/TC $6 / \mathrm{SC} 5 /$ WG 1 the United Kingdom proposal, document $6 / 5 \mathrm{~N} 223$, amended as suggested by the United Kingdom in document $6 / 5 / 1 \mathrm{~N} 50$, was agreed upon in principle. The revised draft, document $6 / 5 \mathrm{~N} 410$, is being considered simultaneously by subcommittee SC 5 and workj.ng group 1 .

Sampling of unitized bales for moisture testing

A draft based on the principle presented by Finland is being considered by the working group.

Revision of ISO Recommendation R 801 .

Comments were made during the Berlin meeting of SC 5 to the effect that the test piece drying procedure should be revised. In addition to the proposals made in connection with the revision of ISO Recommendation R 638 to change the basic drying temperature, no definite suggestions for revision have been made. Any available information would be very much welcomed. 
Statistical evaluation of: number of sample bales

The development of a statistical method for the determination of saleable mass was first discussed in Montreal in 1967. The discussions were continued in Os.10 in 1969, in London in 1970, and in Berlin in 1972. A method was submitted prior to the Berlin meeting, but some of the statistical methods used were questioned. The United States delegates subsequently submitted a report on this question. This report was presented to the members prior to the meeting. Three major points were discussed.

1. There was a question concerning the number of degrees of freedom to be used in selecting the " $t$ " value used in calculating the confidence limits. The secretariat is to contact ISO/TC 69 on Application of Statistical Methods for advice on this question.

2. The formula to be used for calculating the confidence limits was discussed. Two formulas are available with the choice of the formula depending upon the type of variation present. In this method, both types of variation are present and neither formula is correct. The formula used in this method always gives confidence limits which are too narrow, the other gives confidence limits which are too wide. The decision as to which should be used was postponed until the next meeting.

3. It was agreed that the method could not be used unless at least 24 bales were sampled. The previous method permitted as little as 12 .

Saleable mass of flash dried pulp

The subject of testing flash dried pulp was first discussed in 1964 and has been on the agenda of every meeting since. A special boring tool has been developed for drilling these bales, and a method has been written around this tool. The United States has encountered diffculty with this tool but had nothing better to offer. Therefore, the method was accepted after a statement was added concerning the problems which might be encountered with certain types of pulp. A few other editorial changes were made and the method was then approved by the working group for submission to SC 5 . 
Sampling unitized bales for moisture testing

A method for sampling unitized bales was submitted prior to this meeting. It specified the sampling of three bales from each unit sampled, with the number of units sampled to be equal to the square root of the number of units shipped. There was some question concerning the statistical approach and the desirability of sampling six bales in each unit. The United States representative on this working group is to collaborate with the Finnish delegate in developing a satisfactory technique.

Revision of ISO Recommendation R 801, Saleable Mass of Pulp

This method had been presented to Iso member countries for ballot to advance it to an ISo standard but had failed to get the number of votes needed for advancement. Therefore, it was returned to SC 5 for revision.

It was agreed that the drying temperature should be increased to $105 \pm 2^{\circ} \mathrm{C}$. This is in accordance with the TAPPI standard. No other changes were made. The method will now be processed through SC 5, TC 6 , and Iso member bodies. If it is approved by a majority of the member bodies but fails to obtain enough votes to make it an ISO standard, it will be reissued as a revised Iso recommendation.

Canadian Method

A copy of the Canadian Method was submitted for consideration of the working group. Canada pointed out that this method is a statistical method and suggested that it replace R. 801 and the proposed statistical option being considered for $R$ 801. Because it was submitted at the meeting there was very little discussion. Comments can be submitted by mail, and it will be discussed at the next meeting. 
6. REPORT ON MEETING OF WORKING ("ROUP 6, AQUEOUS EXT'RACTS

\subsection{Agenda of Meeting}

The second meeting of ISO/TC $6 / \mathrm{SC} 5 /$ WG 6 was held at Instituto Nacional de Investigaciones Agrarilas, Avenida de Puerta Hierro, $s / n$, Madrid, Spain, on Monday, 5 th November 1973, at 2 p.m.

1. Opening of meeting

2. Election of chairman

3. Approval of draft agenda

4. Preparation of standard extracts

documents: ISO/TC 6/SC 5/WG 6 (Secretariat-15) 28 ISO/TC $6 /$ SC $5 /$ WG 6 (Secretariat-18) 35

5. Letermination of $\mathrm{pH}$ of standard extracts

documents: ISO/TC 6/SC 5/WG 6 (Secretariat-16) 29 ISO/TC 6/SC 5/WG 6 (Secretariat-18) 35

6. Determination of conductivity of standard extracts

documents: ISO/TC 6/SC 5/WG 6 (Secretariat-17) 30 ISO/TC 6/SC 5/WG 6 (Secretariat-18) 35

7. Determination of surface $\mathrm{pH}$ of paper

documents: ISO/TC 6/SC 5/WG 6 (Germany-4) 31

ISO/TC $6 / \mathrm{SC} 5 /$ WG 6 (Sweden-1) 32

ISO/TC 6/SC 5/WG 6 (Finland-3) 34

ISO/TC 6/SC 5/WG 6 (Finland-4) 36

ISO/TC 6/SC 5/WG 6 (Secretariat-19) 37

8. Determination of sulphate and chloride in aqueous extracts

documents: ISO/TC $6 / \mathrm{SC} 5 /$ WG 6 (Netherlands-1) 4

ISO/TC 6/SC 5/WG 6 (Germany-1) 10

I.SO/TC 6/SC 5/WG 6 (Germany-2) 11

ISO/TC $6 / \mathrm{SC} 5 /$ WG 6 (United Kingdom-2) 21 


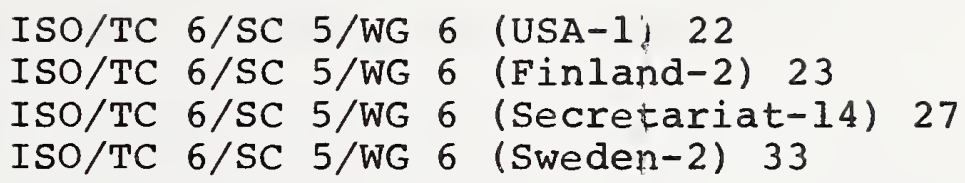

9. Program of future work

10. Other questions

11. Closing of meeting 
6.2 Secretariat memorandum of september 1973

Preparation of standard extracts

A revised working draft has been prepafed based on comments by the Working Group members and information from documents of ISO/TC 91, Surface Active Agents. As instructed by the Berlin meeting of ISO/TC 6/SC 5, the Working Group requested to re-examine the practicability of preparing one single standard method for the preparation of aqueous extracts.

Determination of $\mathrm{pH}$ and conductivity of standard extracts

Revised proposals have been submitted to the Working Group members for comments and discussion at the next meeting.

Determination of surface $\mathrm{pH}$ of paper

As agreed by the Berlin meeting of SC 5 this method will be considered in relation to paper and board only. Several comments on the German proposal, document $6 / 5 / 6 \mathrm{~N} 31$, have been received and counter-proposals have been presented by Finland and Sweden.

Determination of sulphate and chloride content

As a result of the request of the Berlin meeting of SC 5, one comment only, by Sweden, has been presented on the applicahility of the various methods for determination of sulphate and chloride content of aqueous extracts. It is hoped that based on the test results presented in the Swedish comments together with those received earlier, it will be possible at the next working group meeting to agree on the line of progress.

Program of future work

No proposals in regard to the two items included in the program of future work, viz., determination of acidity and basicity have been made.

Meeting of ISO/TC $6 /$ SC $5 /$ WG 6

Working Group ISO/TC 6/SC 5/WG 6, Aqueous Extracts, will meet in Madrid on November 6, 1973. The draft agenda includes all the above items and any results of the discussions will be reported at the subcomittee meeting. 


\subsection{Discussion at Working Group heeting}

Preparation of standard extracts

Document (Secretariat-15) 28, Paper, Board, and Pulps-Preparation of Standard Extracts, was accepted in principle. It was agreed that both hot and cold extraction is needed and that the weight should be expressed on an oven-dry basis.

Later in the meeting it was agreed that each method ( $\mathrm{pH}$, conductivity, etc.) should be self-contained. This was realized when it became necessary to add a plethora of notes concerning differences in precision of measuring weight of pulp and volume of water for the extraction procedure for subsequent test methods.

Determination of $\mathrm{pH}$ of standard extracts

Document (Secretariat-16) 29, Paper, Board, and Pulps-Determination of $\mathrm{pH}$ of Standard Extracts, was accepted in principle. Hot and cold extraction, based on 2 grams $\pm 0.1 \mathrm{~g}$ per $100 \mathrm{ml}$ should be included in the method, but not extraction with sodium chloride solution. An ad hoc group decided that the method should be limited to a conductivity value of $2 \times 10^{-4} \mathrm{~S} / \mathrm{m}$, below which the $\mathrm{pH}$ value of an extract would not be valid. The Secretariat will revise the method and submit it to the working group for comment.

Determination of conductivity of standard extracts

It was agreed that conductivity should be determined only on a hot extract of 2 grams $\pm 0.002 \mathrm{~g} / 100 \mathrm{ml}$.

Alum is used during the washing of some pulps to help eliminate pitch, and hot and cold extraction would give different results.

Although it was not mentioned at the meeting, extraction of anions and cations from pulp with water is almost never complete. Therefore, a standard procedure is necessary in order to achieve comparable results.

With respect to temperature of measurement, the method reads, "...measure at $25^{\circ} \pm 0.2^{\circ} \mathrm{C}$." A decision concerning a choice between measuring at $25^{\circ} \mathrm{C}$ and measuring at a temperature near $25^{\circ} \mathrm{C}$ and converting to $25^{\circ} \mathrm{C}$ via tables was left to the Secretariat. 
Determination of surface $\mathrm{pH}$ of paper

It was agreed that a method was needed for paper but not for pulp. There was considerable resistance to the surface pH determination because of its unreliability and lack of precision. It was pointed out, however, that this is a matter of degree rather than kind, as most methods for pulp and paper are empirical and subject to considerable variability. Only recently has it become standard practice to write precision statements into methods.

It was concluded that the personnel of three countries (Germany, Finland, and Sweden) should get together and finalize a method to be forwarded to SC 2 not later than February 1974.

Determination of water soluble sulphate and chloride

It was agreed that the Finnish method, (Finland-2) 23 , is a suitable one and that determinations of sulphate and chloride should be written as separate methods and finalized.

A 5-gram sample should be used for greater precision.

The determination of chloride should not be confined to electrical papers.

It was concluded that there is a real peed for measuring chloride and sulphate in paper.

A table showing the range and accuracy of the proposed methods will be distributed. Sweden will study methods for the determination of sulphate.

Program of future work

The consideration of acidity and basicity was assigned to WG 6 at the Oslo meeting in 1969. In view of the lack of interest, the working group agreed to recommend to SC 5 that acidity and basicity not be considered further. In view of possible interest by other ISO committees, WG 6 recommends to SC 5 that active contacts with other ISO committees interested in this work should be maintained. 


\section{REPORT ON MEETING OF WORKING GROUP 8, PREPARATION OF LABORATORY SHEETS FOR PHYSICAL TESTING}

\section{I Agenda of Meeting}

The second meeting of ISO/TC $6 / \mathrm{SC} 5 /$ WG 8 was held at the Instituto Nacional de Investigaciones Agrarias, Avenida de Puerta Hierra, $s / n$, Madrid, Spain on Tuesday, November 6 , 1973, at 9 a.m.

Sweden is the convenor of the group, and Dr. Bethge chaired the meeting.

1. Opening of the meeting

2. Election of chairman

3. Approval of draft agenda

4. Preparation of laboratory sheets

A report of the present status of work will be presented at the meeting.

document: ISO/TC 6/SC 5 (Secretariat-189) N 406

5. Testing the physical properties of laboratory sheets

(document will be distributed by post before the meeting)

6. Future work

7. Other questions

8. Closing of meeting 
7.2 Secretariat Memorandum of September 1973

The Secretariat of ISO/TC 6/SC 5/WG 8, Sweden, has, following the decisions made at the Berlin meetings of the working group and SC 5, prepared a working draft for the method of testing the physical properties of laboratory sheets of pulp.

The object of this method is to form a link between the present sheet forming method, document $6 / 5 \mathrm{~N} 406$, and the various methods used for testing laboratory sheets.

The method does not include the various physical test methods. In most cases, the paper testing methods can be appli.ed and reference is made to these methods (with exception for the light-scattering coefficient). Only when determinj.ng tensile strength, the test piece length is reduced from $180 \mathrm{~mm}$ to $100 \mathrm{~mm}$.

The sheet forming method, accepted in principle by SC 5 , allows test sheets of different sizes and shapes, which means that no precise instructions for cutting of test pieces can be given. The number of test pieces to be tested is less than reconmended in paper testing. Otherwise, it would be impossible to make a complete testing with the amount of pulp obtained from one beating point. It should be observed that the figures given indicate the minimum number of tests.

The instructions for reporting are less comprehensive than in the corresponding paper testing methods. One reason for this is, of course, that the sheets have no machine and cross directions. Another reason is that a full report, giving all possible details, including measures of dispersion, for a complete pulp evaluation, would become a very complicated document.

For the strength properties tensile, tear, and burst, only the breaking length and the tear and burst indexes need to be reported.

For tear and burst the indexes should be given, not the factors. This is in accordance with decision taken at the Philadelphia meeting of TC 6/SC 2 in september 1972 (see document TC $6 / \mathrm{SC} 2 / \mathrm{N} 598$, Resolutions 2 and 3 ). This is in line with the SI rules. 


\subsection{Discussion at Working Group Meeting}

Sweden has been the convenor of this group since the liondon meeting in 1970. At the Berlin meeting in 1972, a method was presented to the working group which embodied the most important principles of uniform handsheet preparation, while still allowing different types of equipment. The only major type of equipment which fell outside the scope of this general method is the Rapid-Kothen method favored by Germany. It was agreed at Berlin that Germany would prepare a draft of the Rapid-Kothen method for future consideration. A revised draft of the general sheetmaking method, reviewed at Berlin, was circulated prior to the Madrid meeting.

At the Madrid meeting the major portion of the effort was concerned with a review of $6 / 5 / 8 \mathrm{~N} 14$, a draft proposal for testing the physical properties of laboratory sheets. The object of this method is to form a link between the sheet forming method and the various methods used for testing laboratory sheets. Since the general sheetmaking method allows sheets of different sizes and shapes to be prepared, no cetailed procedure for sample cutting is included. In general, the method refers the user to the appropriate paper testing method. One important difference is that fewer test replications are made, since not as much sample is available as when testing paper. The method does not include brightness testing.

The major focus of the discussion concerned the basis of grammage; whether it should be on an air-dry or an oven-dry basis. All of the delegations present, except Canada and the United Kingdom, preferred the air-dry basis. Those in favor of the air-dry basis felt that all pulps hold a characteristic level of moisture which in part affects physical properties and that expression on an oven-dry basis does not correct for the moisture content. Those in favor of an oven-dry basis felt that this method expresses the results on a uniform basis. It was not possible at the session to reach a consensus, so it was decided to present the problem to the SC 5 plenary meeting .

In other discussion, it was decided to include references to the Rapid-Kothen method in the scope, to delete the reference to the measurement of light scattering coefficient, and to modify the breaking length procedure to specify a time-tobreak rather than a rate of elongation. 
It was agreed that the method would be revised by the convenor and redistributed to members who would then have six months to submit comments. The comments would be incorporated into the method and then the method submitted to SC 5 .

Although not on the agenda, there was time remaining and a desire by the group to discuss the document regarding sheet preparation, 6/5 $\mathrm{N} 406$. In this discussion, it was decided to mention the Rapid-Kothen method in the Scope, to mention the fact that this method does not cover the preparation of handsheets for brightness determination, and that both pressings shall be at $400 \mathrm{kPa}$. Further discussion of this document was cut off for lack of time.

Finally, it was decided that members would have six months to review and submit comments regarding $6 / 5 \mathrm{~N} 432$, the RapidKothen method submitted by Germany just prior to the meeting. It was agreed that if the comments are minor, the revised draft would go directly to SC 5 . 
8. REPORT ON MEETING OF WORKING GROUP 1 OF SC 2, OPTICAL PROPERTIES OF PAPER, BOARD, AND PULP

\subsection{Agenda of Meeting}

The meeting was held on 2 November 1973 at the Instituto Nacional de Investigaciones Agraria, Avenida de Puerta Hierro, $s / n$, Madrid, Spain.

1. Opening of meeting

2. Approval of draft agenda

3. Discussion on the following documents

ISO/TC $6 /$ SC 5 (Sweden-12) 417

ISO/TC 6/SC 5 (Secr.-203) 423

(These two documents are mentioned in the agenda of the meeting of TC $6 / \mathrm{SC} 5$, see item 13)

ISO/TC 6/SC 2/WG 1 (Sweden-13) 96

ISO/TC 6/SC 2/WG 1 (Secr.-43) 97

(These two documents are distributed with this draft agenda)

4. State of "Calibration of Reflectometers"

5. Discussion of comments on $6 /-/ 1 \mathrm{~N} 23$, International Calibration of Testing Apparatus

6. Gloss measurements

7. Other questions 
8.2 Secretariat memorandum of september 1973

\section{Blue reflectance factor of pulp}

Document $6 / 5 \mathrm{~N} 408$, Determination of Diffuse Blue Reflectance Factor (ISO Erightness) of Pulp; a draft proposal revised in accordance with the results of an interlaboratory test, was submitted in June 1973 to the subrommittee for comment. In consequence of the results of the test, the Secretariat suggested that, for the arying of the test sheets, the $4 \mathrm{hr}$. air-drying procedure should be adopted. Comments on the document were requested by 1973-07-10. No comments of significant technical importance were male, and after certain minor adjustments, the method is now being sent to the secretariat of ISO/TC 6 for processing.

Sweden suggested that additional interlaboratory experiments be made to investigate the reasons for the surprisingly large differences in brightness values obtained from the same sample in different laboratories. Seven laboratories in Canada, Finland, France, Norway, South Africa, Sweden, and the U.S. have agreed to participate in these experiments which will be performed under the condition that no further delay will be caused in handling of the draft proposal. Results of this experiment are expected by October 1973.

\section{Light scattering coefficient}

A working draft has been submitted by Sweden and the method is being considered by the working group. 
8.3 Discussion at Working Group Meeting

This working group is part of $\mathrm{SC} 2$, but also reports to sC 5. Canada became the convenor of this group when the chair was relinquished by the United Kingdom in 1972, and wolfgang Budde is the chairman.

The principal interest of SC 5 in this working group is the determination of pulp brightness. A method for the determination of diffuse blue reflectance factor of pulp was submitted some years ago, but has not yet been adopted. At the London SC 5 meeting, it was concluded that EDTA solution should be added to all pulp suspensions and that the $\mathrm{pH}$ of the suspensions should be adjusted to 4.0-5.5. At the Berlin SC 5 meeting, Finland proposed an LiCl drying procedure, and it was agreed to carry out laboratory tests to compare the LiCl procedure with air drying for the preparation of brightness handsheets.

Since then two round-robin laboratory tests have been carried out, and the United States participated in both. The conclusion was that the LiCl method presented no advantage, so it was decided to permit only the air drying technique for the preparation of brightness handsheets. These tests also showed that the Elrepho brightness tester gave reproducible results, and that the reproducibility and repeatability of the handsheet preparation procedure was reasonably good.

At the working group meeting the results of this work were reviewed and considerable time was spent reviewing document $6 / 5 \mathrm{~N} 408$, Pulps-Determination of Diffuse Blue Reflectance Factor. A number of minor changes were made, mainly editorial. The most important change was to prohibit the use of a kitchen mixer for disintegrating the pulp. Instead, the ISO recommendation for wet disintegration using the British disintegrator will be used, although this will give lower brightness results. The consensus was that this technique is more reproducible. Another change in the method was to clarify the sheet drying procedure; it will be recommended that the sheet be freely suspended in a current of air.

Considerable discussion followed regarding the need to set up reliable "standardizing" laboratories capable of measuring absolute reflectances. Canada and Sweden aIready have this capability, and participation of the National Bureau of standards is desired. The standardizing laboratories 
would then supply "authorized" laboratories with calibrated standards of Level 2, so that the authorized laboratories could issue standards of Level 3 to industrial concerns and others who make brightness measurements. There seemed to he considerable confusion as to how this mechanism would be set up.

The group briefly discussed the measurement of gloss, indicated its dissatisfaction with the TAPPI methods, and requested suggestions for an improved technique. Also, the interest of the working group in developing methods for opacity determination and color measurement was indicated. A document before the group regarding light scattering determination was briefly reviewed. It was agreed that the development of this method would be useful, but that it would take time and it was concluded that this measurement should not become part of the current SC 5/WG 8 proposal for testing pulp handsheet properties.

The importance of setting definite dates for switching to the absolute reflectance basis and for the change to the pulp brightness handsheet technique was emphasized. It was recommended that TC 6 be made aware of the need for effective advance publicity in this regard, so that the buyers and sellers of pulp can make the necessary adjustments.

It would seem very appropriate that a standardizing laboratory be established in the United States equipped to measure ahsolute reflectances, and the National Bureau of Standards appears to be the proper place. The absolute basis is certain to become the standard for reflectance measurements, not only for paper but also for other materials where color and brightness are important. It is very likely that by the end of 1974, the absolute basis will be internationally adopted for reflectance measurements of paper. This constitutes an important commercial change because it will effectively lower brightness numbers. Therefore, the full participation of the United states, which is the country most involved in the buying and selling of papermaking pulp, is important. 
9. REPORT ON TECHNICAL SESSIONS DF SC 5

\subsection{Opening of the Meeting}

The Ninth meeting of: ISO/TC $6 / \mathrm{SC} 5$, Testing Methods and Quality Specifications for Pulp, was held November 6-8, 1973, at Instituto Nacional de Investigaciones Agrarias, Madrid, Spain. Dr. Antonio Fernandez, speaking for the Instituto Nacional de Investigaciones Agrarias, welconed the delegates and gave a brief description of the pulp and paper industry in Spain.

Prof. Waldemar Jensen of Finland, continuing chairman of SC 5, assumed the chair and thanked the Spanish hosts for their generous hospitality.

Working hours were set forth as follows:

Tuesday, $13: 30-17: 30$

Wednesday, 9:00-12:00 and $14: 00-17: 30$

Thursday, $9: 00-12: 30$ and $14: 00-17: 30$

A tour of the Spanish Paper Institute was scheduled for Wednesciay afternoon.

The secretary read the list of participating members of SC 5 (section 2 of this report).

The secretary read the list of countries represented at the meeting and the names of the delegates (section 14.2).

The draft agenda, 6/5 (Secretariat-198) 418, was approved with the addition of several documents, and a revised agenda is given in 14.1 .

At previous meetings, brief minutes have been distributed, but this practice was discontinued at the Madrid meeting. Instead, draft resolutions were carefully prepared and read at the end of each agenda item.

Mr. Hutley of the United Kingdom and Mr. Habert of France were appointed to the editing committee. 


\subsection{Saleable Mass, in Lots, of Pulp}

Action Prior to Meeting

This is summarized in section 5, Report on Meeting of Working Group 5, Saleable Mass of Pulp.

\section{Nction at Meeting}

Mr. Lassenius, chairman of the working group, presented a report of the Monday meeting with the recommendations of the working group. After some discussion, SC 5 approved these recommendations. They can be summarized as follows:

1. The method for flash-dried pulp is to be submitted to TC 6 after the revisions recommended by fhe working group are made.

2. $\mathrm{R} 801$, the present ISO method for saleable mass, is to be revised by changing the drying temperature to $105^{\circ} \mathrm{C}$ and is then to be submitted to TC 6 for balloting as an ISO Standard.

3. The working group is to study the Canadian proposal to determine the advisability of a further revision of $\mathrm{R} 801$.

4. The working group is to continue the work of developing a statistical method to be issued as an amendment to $R 801$ and is to also continue its work to develop a method for sampling unitized lots. 


\subsection{Disintegration for Tests on Unbeaten Pulps}

Action Prior to Meeting

At the 1968 meeting in Helsinki, it was agreed that each laboratory beating method should include its own method for disintegration, but that in addition a separate method should be prepared to describe disintegration of pulp for other testing purposes. Since then it has been agreed that this will be done using the British disintegrator, and there never has been any serious consideration of any other equipment.

For some years Norway has been concerned with the conditions of disintegration for flash-dried mechanical pulp. During the past year some laboratory work was carried out, with the participation of the United States. The conclusion of this work, presented in $6 / 5 \mathrm{~N} 412$, was that a soaking time of 10 minutes for flash-dried pulps, regardless of their $\mathrm{pH}$ value, would be adequate. On that basis, document $6 / 5 \mathrm{~N} 359$, which first was reviewed by SC $5^{*}$ in Berlin, was again put on the agenda for the Madrid meeting. Several changes in $6 / 5 \mathrm{~N}$ 359, noted in the minutes of the Berlin meeting, have not yet been implemented.

Action at Meeting

At Madrid the discussion centered on $6 / 5 \mathrm{~N} 359$, draft proposal on disintegration for tests on unbeaten pulps. It was agreed that the title would be changed to "Laboratory Wet Disintegration for Pulp," and that examples for the use of this method would be added under scope. Several other editorial changes were noted, none of any real substance. No further changes were made in the technique, equipment, or conditions of disintegration.

This method is handled directly by the SC 5 secretariat, and no working group is involved. It was agreed that the Secretariat would prepare a revised draft and submit it to the members. If approved, it would be submitted directly to TC 6 without waiting for the next SC 5 meeting. 


\subsection{Laboratory Beating of Pulp}

Action Prior to Meeting

In Helsinki in 1968, four ad hoc working groups were formed to prepare methods for the laboratory beating of pulp. These four groups were to deal with the Lampen mill, the Jockro mill, the Valley beater, and the PFI mill, respectively. At the Berlin meeting, it was decided to drop futher consideration of the Lampen mill. The methods for the PFI and Jockro mills have been completed for some time, and only additional work on the valley beater was required after the Berlin meeting. At Berlin, the Secretariat was asked to prepare a revised draft on the valley beater method and to submit it to SC 5 members by mail.

Action at Meeting

There was very little substantial discussion. Sweden had presented some comments regarding the Valley beater in $6 / 5 \mathrm{~N} 434$, and these were reviewed and generally adopted, but they were mainly editorial in nature.

At the Berlin meeting it had been decided to add a note to all the beater methods indicating some superiority to the PFI mill. The value of this note was discussed, and Canada indicated that it felt it constituted an advertisement for the device. After some deliberation, it was agreed to retain the note.

There was little or no comment regarding the other mills. The secretariat was instructed to prepare revised drafts and forward them to TC 6 . 


\subsection{Preparation of Laboratory Sheets}

Action Prior to Meeting

This work has been under the jurisdiction of working Group 8, Preparation of Laboratory Handsheets for Physical Testing, with Sweden as the convenor. The goal of the group is to develop a single sheet forming method which can be adapted to most sheet-forming equipment. The problem has been that a general sheetmaking procedure developed by the group will not work with the Rapid-Kothen method, and Germany has insisted that the Rapid-Kothen method be included. At Berlin, it was agreed that a separate method would be prepared for the Rapid-Kothen technique, but that it would be used only when the pulp is beaten with a Jokro mill. Further, at Berlin, it was agreed that if two sheet forming methods are approved with the above stipulation, then both methods would be equally considered anew if the Jokro method is dropped as an ISO recommended method some time in the future.

The general sheetmaking procedure under consideration in document $6 / 5 \mathrm{~N} 406$, circulated prior to the Madrid meeting, stipulates that there shall be no sheet shrinkage during drying, and that the sheets will dry to equilibrium with the conditions at which they will be tested. The method encompasses the British sheetmaking technique commonly used in the United states. The document was briefly discussed at the working group meeting reported in section 7 of this report. However, there was not sufficient time at the WG meeting for a complete reviers and discussion.

Immediately prior to the SC 5 meeting, Germany circulated $6 / 5 \mathrm{~N} 432$, a draft proposal for the Rapid-Kothen method. This was the method they had promised at the Berlin session to prepare. There was no discussion of this method at the WG level, except it was indicated that members should submit their comments within six months. If the comments are minor, the document will be forwarded directly to SC 5 .

\section{Action at Meeting}

At the meeting an attempt was made to review document $6 / 5 \mathrm{~N} 406$, a draft proposal for the preparation of laboratory sheets. However, because of lack of time and the great interest in this subject, an ad hoc committee was set up to handle this task. This group consisted of representatives of 
Finland, Sweden, Germany, United Kingdom, United States, and portugal, and it met soor after formation for about six hours. It agreed, in addition to the points mentioned in section 7 of this report, to modify the scope to indicate that brightness measurements cannot be made on these sheets; to indicate in Field of Application that the method is not suitable for long-fibered pulps; to add the British mesh description in section 4.1 (c); to mention under Equipment the need for a means to release vacuum under the septum; to amplify the blotter specification; to indicate that the drying plates should be flat; and to largely rewrite the section on drying and conditioning to clarify the essential points. In addition, several other smaller editorial changes were made.

The ad hoc group reported back to SC 5, and its report was accepted without further comment. A new draft of $6 / 5 \mathrm{~N}$ 406 will be prepared by SC 5 and submitted directly to TC 6 . 
9.6 Testing of Physical Properties of Pulp

\section{Action Prior to Meeting}

This work comes under the responsibility of WG 8 , Preparation of Laboratory Handsheets for Physical Testing. This working group held a meeting just prior to the SC 5 plenary session, and the actions taken at that meeting are described in section 7 of this report. In brief, at the working group session, considerable time was spent reviewing document $6 / 5 / 8 \mathrm{~N} 14$, a draft proposal for testing the physical properties of pulp.

\section{Action at Meeting}

The report of the working group was accepted without significant comment. The WG indicated that it had not been able to resolve the grammage calculation, as reported in section 7, and asked the secretariat for guidance. Canada and the United Kingdom, the only two countries wanting an oven-dry basis, indicated that they would not insist to the extent of slowing the adoption of the method, and in this way a consensus was. reached. The method again is in the hands of the working group. The convenor of the WG will prepare a revised draft and submit it to the WG members. If no important comments are received within six months, the method will then be submitted to SC 5 . 


\subsection{Viscosity of Pulp}

Action prior to meeting

The Secretariat of ISO/TC $6 /$ SC $5 /$ WG 4 , Viscosity of Pulp, had prepared for comment of the membefs of the working group a revised working draft for the determination of viscosity by the CUEN method. The members also were fequested to consider whether two alternative methods of determination of viscosity should be recommended, viz., the CUEN and the EWNN methods.

These two methods, together with a report on the work of ISO/TC 6/SC 5/WG 4, were discussed at the Paris meeting of ISO/TC 38/SC 16, Textlles/Chemical Testing, in February 1973. They agreed that further experiments would be necessary before any choice was possible.

IEC/TC 15, Insulating Materials, is considering a method for the determination of intrinsic viscosity of papers for electrical purposes. This method, a CUEN method, is very similar to that considered by ISO/TC $6 /$ SC $5 /$ WG 4.

Action at Meeting

As very little has been done since the last meeting, the U.S. suggested that action was urgently needed. The group agreed, and the urgency resolution (No. 10) proposed by the U.K. was adopted. 
9.8 Aqueous Eixtracts of Paper and Pulp

Action Prior to Meeting

This is summarized in section 6, Report on Meeting of Working Group 6, Aqueous Extracts.

Action at Meeting

Mr. Lassenius reported on the meeting of the working group, and this report was accepted.

Sweden suggested that the working group should act as soon as possible, along the lines mentioned in the report, and Resolution No. 11 covering this suggestion was approved. 
9.9 Dirt and Shives in Pulp

\section{Action Prior to Meeting}

Experiments have been made in Finland in order to determine whether changes occur in the dirt and shives content of pulp during the sheet making procedure. Under the conditions prescribed in the proposed method, changes were not observed. In addition to the standard sheet making procedure described in $6 / 5 \mathrm{~N} 406$, fully satisfactory test sheets can be made using a very simple sheet making device.

A revised working draft is now being considered by WG 7 . The revised draft takes into account the various amendments agreed upon at the Berlin meeting. Comments were requested by $1973-11-04$.

\section{Action at Meeting}

Finland reported that a proposal was not yet forthcoming from the working group, and suggested that action not be taken at this time. The problem was left to the working group. 
9.10 Determination of Total Sulphur Content

\section{Action Prior to Meeting}

At the last meeting of SC 5 , the determination of total sulphur content of pulps was discussed. The subject had been raised by Sweden who had, for information, submitted a method, $6 / 5 \mathrm{~N} 332$, based on the Schoninger burning technique. Sulphate ions are determined indirectly by precipitation with barium chloride and conductometric titration of excess reagent with lithium sulphate solution.

The Subcommittee agreed in principle that a method for the determination of total sulphur content was necessary. Attention was, however, drawn to the risk of explosion when using the method presented by Sweden.

The Secretariat was instructed to contact other committees dealing with total sulphur determination, such as TC 47 , Chemistry. Contact has been made, but no information has been received.

Sweder had submitted a report, $6 / 5 \mathrm{~N} 416$, on the comparison of various methods for determination of sulphate ion, and this is reproduced in section 14. Appendix.

Action at Meeting

It was agreed that the draft proposed by Sweden, $6 / 5 \mathrm{~N}$ 332 , was the best, but instructions must be given for avoiding explosions.

Sweden was invited to submit a revised proposal (Resolution No. 22). 
9.11 Optical Properties of Pulp

Action Prior to Meeting

Working group 1 of SC 2, dealing with optical properties of pulp, paper, and board, also reports to $5 \mathrm{C} 5$. This working group met in Madrid prior to the SC 5 meeting, and a report of its deliberations are found in section 8 .

The main interest of SC 5 in optical properties concerns the measurement of the brightness of pulp. At Berlin a technique for brightness pad preparation was considered which allowed either air drying or an Licl drying technique. Since there was considerable discussion about these alternatives, it was agreed that a series of comparative laboratory tests would be run. Two series of such tests were made, both with the participation of the United States. The conclusion was that the Licl technique holds no advantage, so only the air arying method will be allowed.

The delegations of SC 5 have supported the move initiated by SC 2 to put reflectance measurements, such as brightness, on an absolute basis. Attention has been drawn repeatedly at SC 5 meetings to the need to publicize the date of change to the absolute basis. The change will alter the magnitude of brightness numbers and a considerable quantity of pulp is priced according to brightness. Therefore, the change should take place all over the world at the same time, and the change should be understood by buyers and sellers. There has been considerable confusion about how this change should be organized and when the date of change will be.

Action at Meeting

Mr. Budde, chairman of the working group, reported the results of the WG meeting to the SC 5 session. He noted that a revised draft of $6 / 5 \mathrm{~N} 408$, concerning the determination of diffuse blue reflectance factor of pulp, would be prepared by the working group with the object of recommending to SC 5 that it be submitted to TC 6 without delay.

The importance of adequate publicity regarding the change to absolute reflectance values was treated at some length. The working group target date of July 1, 1974, was accepted by the SC 5 session as being suitable, and the secretariat was asked to try to work out a procedure with TC 6 to properly implement the change, with all urgency. 


\subsection{Revision of ISO Recommendations}

Action Prior to Meeting

It is now the established policy of ISO to revise all ISO recommendations every five years and to advance ISO recommendations to ISO standards whenever possible. Four methods were due for five year revision at this meeting. The method for saleable mass of pulp has already been reported. The other three are discussed below.

\section{Action at Meeting}

$\mathrm{R} 302$, Kappa Number. This was the first recommendation approved by SC 5 and in reviewing it for reaffirmation, it had been suggested that the scope of this method be changed to include semichemical pulps up to 70 percent yield. There was some discussion as to whether yield should be used as a limiting factor, as the user of the pulp does not know the yield. There were several other comments concerning the wording of the present method. It was decided to have the method edited by a working group and then submitted to TC 6 . The working group is also instructed to consider the advisability of preparing a method for a micro Kappa determination. John Tasnian of Canada is the convenor, other representatives are to be appointed by Finland, France, Sweden, and the U.S.

R 638, Dry Matter in Pulp. Two changes were agreed upon, a sample size as small as $2 \mathrm{~g}$ will be permitted and the drying temperature was increased to $105^{\circ} \mathrm{C}$. The Secretariat is to prepare a revised method and submit it to TC 6 .

$\mathrm{R} 777, \mathrm{R} 778, \mathrm{R} 779$, and $\mathrm{R}$ 1830, Trace Metals in Pulp. It was agreed that the methods should be revised to permit the use of atomic absorption techniques where applicable and should then be submitted to TC 6 for ballot. 


\subsection{Canadian Standard Freeness}

Action Prior to Meeting

Canada had submitted a proposal for standardizing screen plates for the Canadian Standard Freeness tester. This recommended that the Pulp and Paper Research Institute of Canada maintain a group of identical screen plates which shall be recognized as the International standard. These would be designated as \#l standards. Level \#2 screen plates would be supplied by PPRIC to any agency which has been nominated as an agency for calibration of screen plates. These Level \#2 screen plates would be calibrated against the Level \#l screen plates. The standardizing agency would use the Level \#2 screen plates to standardize new screen plates for sale to users. These screen plates would be designated as level \#3. Every tenth screen plate calibrated by a secondary calibrating agency would be sent to PPRIC for checking. In addition, any agency nominated to be a calibrating agency would be required to send their master instrument to PPRIC for checking before the agency is approved.

Action at Meeting

Several countries stated that it would be impossible to send every tenth plate to PPRIC because the plates would not helong to them. They also objected to the requirement that the calibrating instruments be sent to Canada. Some editorial changes were suggested.

After some discussion of these points, an ad hoc committee was appointed to prepare a revised proposal. The revised proposal retained the basic system, but made optional the submitting of every tenth plate to PPRIC for checking. A statement that all calibrating instruments must meet all specifications given in the ISO recommendation was substituted for the requirement that the calibrating instrument be sent to PPRIC for checking. This proposal was approved by SC 5 . 


\subsection{Schopper Riegler Freeness}

Action Prior to Meeting

A method for measurement of freeness using the Schopper Riegler instrument had been submitted to letter ballot of SC 5. Some comments concerning the calibration procedure had been received.

\section{Action at Meeting}

It was agreed that the method should be submitted to TC 6 , but that a working group should be established to study the calibration procedure. The United Kingdom will serve as convenor of this working group. Other members will be appointed by Finland, France, Germany, and Norway. The U.S. is not participating because of the relatively small usage of the instrument in this country. A representative can be appointed by the U.S. if this seems desirable. 


\subsection{Accelerated Aging of Pulp}

Action Prior to Meeting

At a meeting of the U.S. Committee for ISO/TC 6 on October 23, 1973, it was agreed that a suggestion be made to the secretariat of SC 5, that the accelefated aging of pulp be placed on the agenda of the meeting of ISO/TC 6/ SC 5 in Madrid, November 2-8.

The accelerated aging of paper is being considered by ISO/TC 6/SC 2," and drafts of methods have been submitted. As the stability of paper depends partly on the nature of the pulp and as brightness reversion of pulp during transit and storage is a problem for both supplier and buyer, this subject might logically be considered by SC 5 .

The U.S. delegation has conferred informally with the Swedish delegation and with Mr. Jack Histed, a Canadian who is a member of the TAPPI Bleaching Committee. Mr. Histed is prepared to write a method for brightness reversion of puIp based on the Finnish steaming device.

Action at Meeting

Background material and a report prepared by Mr. Histed was distributed at the meeting. The secretariat was instructed to send this material, $6 / 5 \mathrm{~N} 446$, to the membership of SC 5, and Mr. Wilson was designated to serve as a focal point for expressions of interest (Resolution No. 21). 


\section{DRAFT RESOLUTIONS}

No. 1

The delegations present instruct the secretariat to prepare an amended text of document 6/5 N 435, Saleable Mass of Flash-Dried Pulps, taking into account the information in regard to the Scandinavian texts to be provided by Norway and the editorial comments to be made by the U.S. They also authorize the secretariat to submit the revised text to the Secretariat of TC 6 for further action.

No. 2

The delegations present agree to proceed with the work on revision of ISO Recommendation R 801 , Saleable Mass, with the object of publishing it as an International standard. They also instruct Working Group 1 to continue to actively study the current Canadian proposals, 6/5/N 60 and 61 , and any others which are relevant, with the object of replacing ISO R 801 with one which is an improvement.

No. 3

The delegations present accept the recommendations of ISO/TC 6/SC 5/WG 1 in document $6 / 5 \mathrm{~N} 436$ regarding the sampling of unitized bales and program of future work.

No. 4

The delegations present instruct the Secretariat to prepare an amended text of document 6/5 N 359, Laboratory Wet Disintegration of Pulp, taking into account document $6 / 5$ N 411 and the comments made at the meeting. The secretariat is authorized to submit the revised document to the secretariat of TC 6 for further ISO procedure.

No. 5

The delegates present authorize the Secretariat to prepare revised texts of documents $6 / 5 \mathrm{~N} 414$ and 415 , Laboratory Beating in the PFI mill and in the Jokro Mill, taking into account the discussion at the meeting, and to pass the methods to the secretariat of ISO/TC 6 for further action. 
No. 6

The delegations present agree that for the time being it may be necessary, for technical reasons, to specify a wire screen different from the current ISO recommendations, in the International standard for preparation of laboratory sheets of pulp. They also advise Working Group 8, if practicable, to continue their studies with the object of applying the Iso specification in due course when the future International Standard preparation of laboratory sheets will be revised.

No. 7

The delegations present advise Working Group 8 to proceed with their studies concerning document 6/5 N 432, Preparation of Laboratory Sheets by the Rapid-Kothen method, on the lines suggested in document $6 / 5 \mathrm{~N} 445$ (report of the working group on the meeting, Madrid, November 6, 1973).

No. 8

It has been agreed that the ultimate aim of standardization of the preparation of laboratory sheets should be to develop one test method which is internationally acceptable; if possible, one which includes the possibility of using different sheet making apparatus.

For practical reasons it has not proved possible to achieve this at present. Therefore, as an interim measure, in view of the wide spread use of equipment described in document 406 and document 432, it has been decided to provide agreed guidance on the use of different equipment in order to achieve consistency of results with each method.

To avoid creating too many levels of results, the method described in document 432 (Rapid-Kothen) should preferably be used in connection with beating according to document 415 (Jokro) only, and the method in document 406 in connection with the beating methods in documents 413 (Valley) and 414 (PFI) on 1 y.

The decision at the Berlin meeting was confirmed stating that when consideration at later stage will be given to a single standard method, the two sheet forming procedures should be given equal consideration.

These comments should be included as introduction in all the methods for preparation of laboratory sheets and the methods for laboratory beating. 
No. 9

The delegations present request Working Group 8 to continue their studies on testing of physical properties of pulp on the lines presented in the report on the WG 8 meeting, document $6 / 5 \mathrm{~N} 445$.

No. 10

The delegates present agree that SC 5 instruct Working Group 4 to prepare draft proposals of the best method or methods for determination of intrinsic viscosity after due consultation and to pass them to the secretariat of the subcommittee for forwarding to TC 6 with urgenfy.

No. 11

The delegates present instruct Working Group 6, Aqueous Extracts of Paper and Pulp, to continue their activities on the lines presented in document $6 / 5 \mathrm{~N} 443$.

№. 12

The delegates present agree to authorize the secretariat to amend the text of document $\mathrm{N} 406$, Preparation of Laboratory Sheets, taking into account the recommendations of the Secretariat of TC 6. At the same time, the secretariat shall submit the method to the members of SC 5 for information.

No. 13

The delegates present have received a report from Working Group SC 2/1 regarding the adoption of the method for measurement of ISO brightness of pulp, 6/5 $\mathrm{N} 437$, and their recommendation that July 1,1974 , be a target date for adoption of the perfect reflecting diffuser as ultimate reference (ISO Reference Standard of Level l).

The delegates present recommend that urgent action be taken by the secretariat of SC 2, SC 5, and TC 6 (and the new ISO body responsible to ISO Council for General International Calibration), to implement the adoption of the WG's suggestions. Further, the delegates request urgent circulation by the WG of advance information relating to the change of ultimate reference and its effects so that national standards bodies may prepare advance publicity in their countries. 
They stress the importance of urgent action by all parties involved in view of the requirements of international commercial interests regarding pulps.

No. 14

The delegations present instruct the secretariat to submit the method for determination of drainability by the Schopper-Riegler method, document $6 / 5 \mathrm{~N} 380$, to TC 6 for further action. They also agree to create a working group, ISO/TC 6/SC 5/WG 11, to consider the revision of the instruction for the calibration of the apparatus in particular.

Finland, France, Germany, Norway, and the United Kingdom will nominate members of the group, and the convenor will be appointed by the U.K.

No. 15

The delegates present note with interest that the information they have received in regard to the work of ISO/TC 6/SC 5/WG 7, Dirt and Shives in Pulp, and advise the working group to continue their work on the lines presented.

No. 16

The delegations present realize that additional studies are required before a proposal for revision of ISO R 302, Kappa Number of Pulp, can be drafted. They instruct a group of experts, including members from Canada, Finland, France, Sweden, and the U.S., to prepare a preliminary draft for consideration of the subcommittee by post and for the document to be submitted to TC 6 . They shall then consider possibilities of preparing a report on the determination of micro-Kappa for the consideration of the subcommittee.

No. 17

The delegates present authorize the secretariat to prepare revised text of document 6/5 N 413, Laboratory Beating of Pulp in the valley Beater, taking into account the discussion at the meeting and the comments presented by Sweden in document 434 as well as comments presented by Canada and U.K. to pass the method to the secretariat of ISO/TC 6 for further action. 
No. 18

The delegations present instruct the Secretariat to prepare a revised text of ISO Recommendation R 638, Dry Matter in Pulp, taking irito account the decisions made at the meeting and to pass i.t to the secretariat of TC 6 with the object of publishing it as an International standard.

No. 19

The delegations presient request the secretariat to prepare definite draft proposals for the revision of ISO Recommendations 777-779 and 1830, Trace Metals in Pulp, in the lines presented in document $6 / 5 \mathrm{~N} 425$ with the object of publishing them as International standards. They also agree that should ISO/TC $6 / \mathrm{SC} 2$ wish to create cooperation in this field, SC 5 would be able to assist them in their work.

No. 20

The delegates present authorized the secretariat to prepare a revised text of document $6 / 5 \mathrm{~N} 426$, Calibration of Canadjan Standard Freeness Screen Plates, taking into account the decisions of the ad hoc working group and to pass the revised proposal to ISO/TC 6 with a request that they should consult the new ISO body responsible to ISO Council for General International Calibration.

No. 21

The delegations present considered that work on aging of pulp may be required and noted the existence of ISO/TC 6/ SC $2 /$ WG 16, Accelerated Aging. They instruct the secretariat to circulate document $6 / 5 \mathrm{~N} 446$ to the members of the subcommittee who will in due time pass their opinions as to the need of this method to Mr. W. K. Wilson, U.S., who has undertaken to act as a focal point for this task.

No. 22

The delegates present invite Sweden to submit to the Secretariat their revised proposal for the determination of total sulphur in pulp; the secretariat, to circulate the proposal to members when it is available. 
No. 23

The delegations present agree to constitute a working group, ISO/TC $6 / \mathrm{SC} 5 / \mathrm{WG} 12$, to undertake the work concerning fiber classification of pulp. Canada, Finland, France, Germany, Norway, and the U.S. will join the working group, Finland accepting the task of the WG secretariat. 
11. PROGRAM FOR FUTURE WORK

1. Saleable mass of pulp in lots WG-1

Statistical method

Flash dried pulp

Canadian method

Pulp in rolls

2. Disintegration of pulp

WG-10

3. Drainage properties

Canadian Standard Freeness

Schopper-Riegler

4. Laboratory beating, including necessary disintegration

WG -10

5. Preparation of laboratory sheets for WG-8 physical testing

6. Testinc of physical properties of pulp WG-8

7. Dirt and shives in pulp WG- 7

8. Optical properties of pulp (in cooperation with $\subseteq C 2$ )

9. Intrinsic viscosity of pulp (no longer in cooperation with TC 38)

10. Aqueous extracts of pulp (in cooperation WG-6 with SC 2)

11. Total sulphur in pulp

12. Fiber classification

13. Sampling pulp for chemical and physical testing

14. Revision of ISO Recommendations

$R$ 302, Kappa Number of Pulp

R 624, Extraction from Pulps of Materials Soluble in Dichloromethane

R 638, Determination of Dry Matter Content

$\mathrm{R}$ 777-779, Trace Metals in Pulp 


\section{TIME AND PLACE OF NEXT MEETING}

The chairman noted that it was seldom possible to announce the exact time and the place of the next meeting at the conclusion of a meeting. The next meeting will be held approximately two years from now. The delegates from one country indicated privately to the secretariat that an invitation should be forthcoming within a few months. The chairman indicated that he would be pleased to have an invitation. 


\section{SPECIAL EVENTS}

On the evening of November 6 , La Association de Investigacion Tecnica de la Industria Papelera Española hosted a dinner for the delegates and their spouses at the Los Porches restaurant in Madrid.

Lunch was served every day to the delegates. A bus from the delegates' hotels to the meeting rooms and return was provided daily. 


\section{APPENDIX}

14.1 Agenda of Meeting of SC 5

1. Opening of the meeting

2. Approval of the draft agenda

3. Appointment of the editing committee

4. Saleable mass, in lots, of pulp

$$
\begin{array}{lllll}
\text { Doc. ISO/TC } & 6 / \mathrm{SC} & 5 & (\text { Secr.-192) } & 410 \\
\text { ISO/TC } & 6 / \mathrm{SC} & 5 & (\text { Secr.-193) } & 411 \\
\text { ISO/TC } & 6 / \mathrm{SC} & 5 & (\text { Secr.-212) } & 435
\end{array}
$$

5. Laboratory disintegration of pulp

$$
\begin{array}{lllll}
\text { DoC. ISO/TC } 6 / \mathrm{SC} & 5 & (\text { Secr.-173) } & 359 \\
\text { ISO/TC } 6 / \mathrm{SC} & 5 & (\text { Secr.-194) } & 412
\end{array}
$$

6. Laboratory beating of pulp

$$
\begin{array}{llll}
\text { DoC. ISO/TC } 6 / S C & 5 & (\text { Secr.-195) } & 413 \\
\text { ISO/TC } 6 / S C ~ & 5 & (\text { Secr.-196) } & 414 \\
\text { ISO/TC 6/SC } 5 & \text { (Secr.-197) } & 415 \\
\text { ISO/TC 6/SC } 5 & \text { (Sweden-13) } & 434
\end{array}
$$

7. Preparation of laboratory sheets

$$
\begin{array}{lllll}
\text { DOC. ISO/TC } 6 / \text { SC } & 5 & \text { (Secr.-189) } & 406 \\
\text { ISO/TC } 6 / \text { SC } & 5 & \text { (Secr.-209) } & 429 \\
\text { ISO/TC 6/SC } 5 & \text { (Germany-5) } & 432 \\
\text { ISO/TC 6/SC } 5 & \text { (Sweden-15) } & 442
\end{array}
$$

8. Testing of physical properties of pulp

Doc. ISO/TC 6/SC 5 (Secr.-199) 419

(The Subcommittee meeting will be preceded by a meeting of ISO/TC 6/SC 5/WG 8 , and a report on their deliberations will be presented.)

9. Viscosity of pulp

Doc. ISO/TC 6/SC 5 (Secr.-200) 420 
10. Aqueous extracts of paper and pulp

$$
\text { Doc ISO/TC 6/SC 5 (Secr.-201) } 421
$$

11. Dirt and shives in pulp

DOC. ISO/TC 6/SC 5 (Secr.-202) 422

12. Determination of total sulphur content

$$
\begin{array}{llllll}
\text { Doc. ISO/TC } & 6 / \mathrm{SC} & 5 & (\text { Sweden-10) } & 332 & \\
\text { ISO/TC } & 6 / \mathrm{SC} & 5 & (\text { Secr.-181) } & 367 & \\
\text { ISO/TC } & 6 / \mathrm{SC} & 5 & \text { (Netherlands-15) } & 374 \\
\text { ISO/TC } & 6 / \mathrm{SC} & 5 & \text { (USSR-5) } & 376 & \\
\text { ISO/TC } & 6 / \mathrm{SC} & 5 & \text { (Sweden-11) } & 416 & \\
\text { ISO/TC } & 6 / \mathrm{SC} & 5 & \text { (Sweden-14) } & 441 &
\end{array}
$$

13. Optical properties of pulp

$$
\begin{array}{lllll}
\text { DoC. ISO/TC } & 6 / \mathrm{SC} & 5 & (\text { Sweden-12) } & 417 \\
\text { ISO/TC } & 6 / \mathrm{SC} & 5 & (\text { Secr.-203) } & 423 \\
\text { ISO/TC } & 6 / \mathrm{SC} & 5 & (\text { Secr.-208) } & 428 \\
\text { ISO/TC } & 6 / \mathrm{SC} & 5 & (\text { Secr.-210) } & 430 \\
\text { ISO/TC } 6 / \mathrm{SC} & 5 & (\text { Secr.-413) } & 437
\end{array}
$$

14. Revision of published ISO Recommendations

14.1 Kappa number of pulp, ISO/R 302 DoC. ISO/TC 6/SC 5 (Canada-6) 409

14.2 Dry matter in Pulp Doc. ISO/TC 6/SC 5 (Secr.-204) 424

14.3 Trace metals in pulp Doc. ISO/TC 6/SC 5 (Secr.-205) 425

15. Canadian Standard Freeness

$$
\begin{array}{lllll}
\text { DOC. ISO/TC } & 6 / \mathrm{SC} & 5 & (\text { Secr.-185) } & 379 \\
\text { ISO/TC } & 6 / \mathrm{SC} & 5 & (\text { Canada-7) } 426 \\
\text { ISO/TC } & 6 / \mathrm{SC} & 5 & (\text { USSR-6) } & 431
\end{array}
$$

16. Schopper-Riegler Freeness

$$
\begin{aligned}
& \text { DoC. ISO/TC } 6 / \text { SC } 5(\text { Secr.-186) } 380 \\
& \text { ISO/TC } 6 / \text { SC } 5(\text { U.K.-Il) } 438
\end{aligned}
$$


17. Accelerated aging of pulp

$$
\text { DOC. ISO/TC } 6 / \mathrm{SC} 5(\mathrm{USA}-6) 446
$$

18. Program of future work

19. Other questions

20. Approval of the resolutions and of the statement of results

21. Date and place of next meeting

22. Closing of the meeting 


\subsection{Delegates to Meeting of sC 5}

Chairman: Prof. W. Jensenn

\section{CANADA}

Mr. J. E. Tasman (leader)

Dr. W. Budde

Mr. E. A. Sexton

\section{FINLAND}

Mr. T. Lassenius (leader)

Mr. J-E. Levlin

Mrs. Liva Vuorilehto

\section{FRANCE}

M. Garnache (leader)

M. Lonvert

M. Habert

\section{GERMANY}

Dr. O. Toppel (leader)

Mr. L. Baumgarten

NORWAY

Mr. $\varnothing . \quad$ Ellefsen

$\underline{\text { POLAND }}$

Mr. Andrzes Winczakiewicz

Mr. Janusz Berndt

$\underline{\text { PORTUGAL }}$

Mr. Veloso Gaio (leader)

Mr. A.F.P. de Campos

Mr. Julio Salvadore

Mr. Manuel Saraiva Santos

SPAIN

Nr. Antonio Xucla (leader)

Mr. Jaime Vidal

Mr. Jose L. Asenjo
Mr. Julio Molieda

Dr. Pedro Barbadillo

Mr. Luis Bustamante

Mr. Jaime Vidal

\section{SWEDEN}

Dr. P.O. Bethige

UNITED KINGDOM

Mr. H. R. Hutley (leader)

Mr. R. Hamer

Mr. G. Youd

UNITED STATES

Mr. W. K. Wilson (leader)

Mr. J. L. Borstelmann

Prof. C. E. Brandon

Dr. J. H. Schulz

OBSERVER: Customs Cooperation

Council: Mr. F. Lobato

Interpreter: Miss M. Girot

Secretariat: Mrs. Heidi Suonuuti 
14.3 Delegates to Eighth Meeting of WG I, Saleable Mass of Pulp

Chairman: Mr. Lassenius, Finland

CANADA

Mr. John Tasman

Mr. Ernest A. Sexton

FINLAND

Mrs. Liva Vuorilehto

Mr. Jan-Erik Levlin

FRANCE

Mr. Hubert Garnache

$\mathrm{Mr}$. Jean Lonvert

\section{GERMANY}

Mr. Heinrich L. Baumgarten

Dr. Otmar Toppel

NORWAY

Mr. Øystein Ellefsen

POLAND

Mr. Janusz Berndt

Mr. Andre Winczakiewicz

SPAIN

Mr. Pedro Barbadillo

SWEDEN

Dr. Per olof Bethge

UNITED KINGDOM

Mr. H. R. Hutley

Mr. G. Youd
UNITED STATES

Mr. J. L. Borstelmann

Prof. C. E. Brandon

Mr. W. K. Wilson

Secretariat: Mrs. Heidi Suonuuti 


\subsection{Delegates to Second Meeting of WG 6 , Aqueous Extracts}

Chairman: Mr. T. Lassenius, Finland

CANADA

Mr. John Tasman

Mr. Ernest A. Sexton

FINLAND

Mrs. Liva Vuorilehto

FRANCE

Mr. Hubert Garnache

Mr. Jean Lonvert

\section{GERMANY}

Mr. Heinrich L. Baumgarten

Dr. Otmar Toppel

NORWAY

Mr. Øystein Ellefsen

SPATN

Mr. J. Vidal

SWEDEN

Dr. Per Olof Bethge

UNITED KINGDOM

Mr. Ronald Hamer

Mr. H. R. Hutley

Mr. G. Youd

UNITED STATES

Mr. J. L. Borstelmann

Mr. C. E. Brandon

Mr. W. K. Wilson

Secretariat: Mrs. Heidi Suonuuti 


\subsection{Delegates to Meeting of WG 8 , Preparation of Laboratory Sheets}

Chairman: Dr. P. O. Bethge, Sweden

CANADA

Mr. E. A. Sexton

Dr. W. Budde

Mr. J. E. Tasman

FINLAND

Mr. T. Lassenius

Mr. J. E. Levlin

Mrs. Liva Vuorilehto

FRANCE

M. Garnache

M. Lonvert

GERMANY

Dr. O. Toppel

Mr. L. Baumgarten

NORWAY

Mr. $\varnothing$. Ellefsen

PORTUGAL

Nr. Manuel Saraiva Santos

SPAIN

Mr. A. Xucla

Dr. Pedro Barbadillo

Mr. Luis Bustamente

UNITED KINGDOM

Mr. H. R. Hutley

Mr. R. Hamer

Mr. G. Youd

\section{UNITED STATES}

Mr. W. K. Wilson

Mr. J. L. Borstelmann

Prof. C. E. Brandon

Dr. J. H. Schulz 


\subsection{Delegates to Meeting of WG 1 of SC 2 , Optical Properties of Paper, Board, and Pulp}

Chairman: Dr. W. Budde, Canada

CANADA

Mr. E. A. Sexton

FINLAND

Mr. T. Lassenius

Mr. Jan-Erik Levlin

Mrs. Heidi Suonuuti

FRANCE

Mr. Jacques L. Poujade

Mr. Robert Seve

GERMANY

Mr. Otmar Toppel

NORWAY

Mr. Qystein Ellefsen

$\underline{\text { SPAIN }}$

Dr. Pedro Barbadillo

SWEDEN

Mr. Ake Stenius

UNITED STATES

Dr. J. H. Schulz 


\subsection{List of Working Groups}

No.

1 Saleable Weight, in Lots, of Pulp Baled in Sheet Form, and of Flash-Dried Pulp

Secretariat: Finland; Convenor: Mr. T. Lassenius Members :

Canada, Finland, France, Germany, Italy, Netherlands, Norway, Sweden, U.K., and U.S.

4 Viscosity of Pulp

Secretariat: Finland

Members :

Finland, Canada, France, Czechoslovakia, Germany, Italy, Netherlands, Romania, Norway, Sweden, U.K., and U.S.

Aqueous Extracts of Pulp. This group is comman to SC 2 and SC 5 .

Secretariat: Finland

Members:

Finland, Sweden, Germany, France, U.S., Italy, Portugal, Australia, Belgium, Spain, U.K., and Czechoslovakia

7 Dirt and Shives in Pulp

Secretariat: Finland

Members :

Czechoslovakia, Finland, France, Netherlands, Norway, U.K., U.S., Sweden, and Italy

Preparation of Laboratory Handsheets for Physical Testing

Secretariat: Sweden; Convenor: Dr. Bethge Members :

Canada, Czechoslovakia, France, Germany,

Italy, Netherlands, Norway, Portugal,

Sweden, U.K., U.S., and Australia

10 Laboratory Beating, Including Necessary Disintegration

Secretariat: Finland

Members :

Australia, Canada, Finland, France, Germany, Italy, Norway, Poland, Portugal, Sweden, U.K., and U.S. 
12 Fiber Classification of Pulp

Secretariat: Finland

Members:

Canada, Finland, France, Germany, Norway, and U.S.

Optical Properties of Pulp

There is no independent working group under SC 5 , but a joint working group exists with SC 2 which reports to SC 2. This is WG 1 under SC 2 .

Secretariat: Canada; Convenor: Wolfgang Budde Members : (list not available) 


\subsection{ISO Recommendations From SC 5}

R 302-1963 Determination of Kappa Number of Pulp

R 624-1967 Cellulose Pulps. Extraction from Pulps of Materials Soluble in Dichloromethane

R 638-1967 Cellulose Pulps. Determination of Dry Matter Content.

R 692-1968 Pulps. Determination of Alkali Solubility

R 699-1968 Pulps. Determination of Alkali Resistance

R 776-1968 Pulps. Determination of Acid Insoluble Ash

R 777-1968 Pulps. Determination of Calcium Content

R 778-1968 Pulps. Determination of Copper Content

R 779-1968 Pulps. Determination of Iron Content

R 801-\$968 Pulps. Determination of Saleable Mass, in Lots, of Pulp Baled in sheet Form

R 1762-1970 Determination of Ash Content

R 1830-1970 Determination of Manganese Content

R 2144-1971 Determination of Ash Content 
14.9 6/5 N 416, Comparison of Methods for Sulphate Ion Determination (from Sweden)

In accordance with the decision taken at the Berlin meeting of ISO/TC $6 / \mathrm{SC} 5$, we have studied some methods for the determination of sulphate ions in dilute aqueous solutions. The primary object of the study was to establish which methods could be recommended for analysis of the adsorption solution obtained after combustion in oxygen atmosphere in the determination of total sulphur in pulp. The results are also of interest for the determination of sulphate ions in aqueous extracts of pulp, which is studied by ISO/TC $6 /$ SC $5 /$ WG 6 .

Our study is not completed yet, but we think that it might be of interest to report on the results obtained so far.

Methods Studied and Summary of Results

1. Precipitation titration with $\mathrm{BaCl}_{2}$ using Alizarine Red $\mathrm{S}$ as the indicator. ISO/TC $6 / \mathrm{SC} 5 \mathrm{~N} 376$.

Approximately $90 \%$ of the amount of $0.05 \mathrm{M} \mathrm{BaCl}_{2}$ solution be added before the indicator is introduced. Titrate to color change from yellow to reddish.

In our hands, the method worked less satisfactorily. The color change was difficult to observe. A preliminary titration is required, which is a serious drawback.

2. Precipitation titration with $\mathrm{Ba}\left(\mathrm{ClO}_{4}\right)_{2}$ using thorin as the indicator. ISO/TC $6 / \mathrm{SC} 5 \mathrm{~N} \mathrm{374}$, method A.

The titration is performed in $80 \%$ isopropanol at $\mathrm{pH} 2-5$. Color change from yellow to pink.

Precise results were obtained with solutions $(5 \mathrm{ml})$ containing $0.33 \mathrm{mg} \mathrm{S}$ and also at higher concentrations. The color change is somewhat difficult to observe.

3. Alkalimetric titration with sodium hydroxide using methy red as the indicator. ISO/TC 6/SC $5 \mathrm{~N} 374$, method $\mathrm{B}$. 
The sample solution is heated to boiling, 'cooled, and titrated with $0.01 \mathrm{NaOH}$.

Precise results were obtained down to a level of $0.1 \mathrm{mg}$ of sulphur in $5 \mathrm{ml}$. The method is, however, not specific; chlorine in the pulp will appear as hydrochloric acid and will be titrated in the same titration.

4. Precipitation titration with $\mathrm{Ba}\left(\mathrm{ClO}_{4}\right)_{2}$, using carboxyarsenazo as the indicator. (Method by Archer, White, and Mackinson, The Analyst 96(1971) 879-880.)

The titration is performed in $67 \%$ acetone in the presence of pyridine. Color change from red to blue.

Precise results were obtained with $0.16 \mathrm{mg}$ of sulphur in $5 \mathrm{ml}$ solution. The endpoint was sharp; further experiments are planned.

5. Conductometric titration with $\mathrm{Li}_{2} \mathrm{SO}_{4}$ after addition of excess $\mathrm{BaCl}_{2}$. ISO/TC 6/SC $5 \mathrm{~N} 332$.

Sulphate ions are precipitated from a solution containing $50 \%$ ethanol with $\mathrm{BaCl}_{2}$, the excess is titrated with $\mathrm{Li}_{2} \mathrm{SO}_{4}$ and the titration is followed by measuring the conductivity of the solution.

The procedure is time-consuming, and the results were less precise.

6. Spectrophotometric determination of $\mathrm{H}_{2} \mathrm{~S}$ after reduction with hydriodic acid. Method in use at the Swedish Forest Products Research Lab.

The sample is evaporated to dryness, hydriodic acid reduction mixture is added and hydrogen sulphide is distilled off and adsorbed in an alkaline solution. The $\mathrm{H}_{2} \mathrm{~S}$ is determined colorimetrically as methylene blue.

The method is less precise than methods 2-4, but can be used down to very low sulphur contents. For $0.008 \mathrm{mg}$ of sulphur in $5 \mathrm{ml}$ sample solution, the results were in the range of $0.0098-0.0077$. 
7. Spectrophotometric determination as phenantroline. Method by Davis and Lindstrom, Analytical Chemistry 44 (1972).

Method similar to 6 , but reduction is made without previous evaporation. The color reaction depends on reduction of $\mathrm{Fe}^{3+}$ to. $\mathrm{Fe}^{2+}$, which forms an orange complex with o-phenantroline.

We plan to test this method at a later date.

\section{Conclusion}

The amount of pulp which conveniently can be burnt in a l-liter oxygen flask is about $500 \mathrm{mg}$. A pulp sample containing 0.1 percent sulphur contains $0.5 \mathrm{mg}$ of sulphur. For such samples the methods 2, 3, 4 seem to be applicable. Method 3 will probably give high results due to chlorine in the pulp especially from bleached pulps, and the endpoint is more difficult to observe in method 2 than in method 4 . It, therafore, seems as if method 4 is best suited for pulps containing 0.1 percent of $\mathrm{S}$ or more.

We plan to continue the experimental work on methods 4 and 7 .

The investigations are carried out at Swedish Forest Products Research Laboratory. 



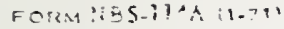

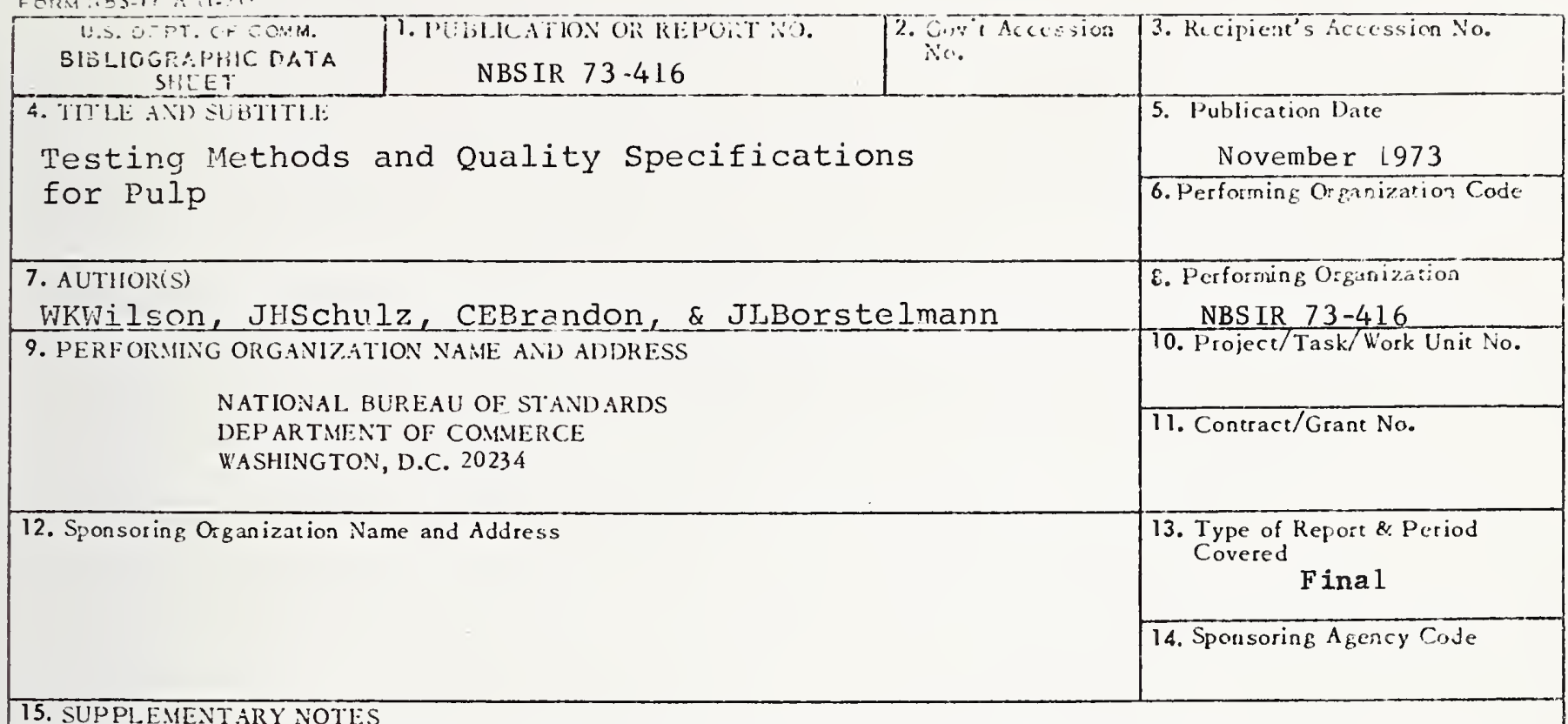

This report describes what happened at an Iso meeting, With the exception of section 3 and section 4 , opinions of the delegates are not expressed.

16. ABSTRACT (A 200-word or less factual summaty of most sibnificant inform.tion. If document includes a significant bibliography or literature survey, mention it here.)

The ninth meeting of ISO/TC 6, Paper, SC 5, Testing Methods for Pulp, was held in Madrid, Spain, November 2-8, 1973. Over 30 delegates from 11 countries discussed methods for testing of pulp and, to some extent, paper. Hethods were agreed upon for the determination of saleable mass of flash dried pulp, disintegration of pulp, laboratory beating of pulp, preparation of laboratory sheets, and measurement of ISO brightness of pulp. It was agreed that ISO Recommendations for determination of saleable mass of pulp in lots, determination of dry matter content, and determination of trace metals in pulp should be revised. Plans were made to continue studies of methods for the determination of viscosity, aqueous extraction, dirt and shives, total sulphur content, saleable mass of unitized lots of pulp, statistical evaluation of number of sample bales, preparation of laboratory sheets, and fiber classification and drainability.

17. KEY WORDS (Alphabetical order, separated by scmicolons)

ISO Recommendations; pulp; pulp, testing methods; testing methods for pulp.

18. AVAILABILITY STATEMENT

[X] UNLIMITED.

FOR OFFICIAL, DISTRIBUTION. DO NOT RELEASE TO NTIS.

\begin{tabular}{|l|c|}
\hline $\begin{array}{l}\text { 19. SECURITY CLASS } \\
\text { (THIS REPORT) }\end{array}$ & 21. NO. OF PAGES \\
UNCL ASSIFIED & 65 \\
\hline $\begin{array}{l}\text { 20. SECURITY CLASS } \\
\text { (THIS PAGE) } \\
\text { UNCL ASSIFIED }\end{array}$ & 22. Price \\
\hline
\end{tabular}








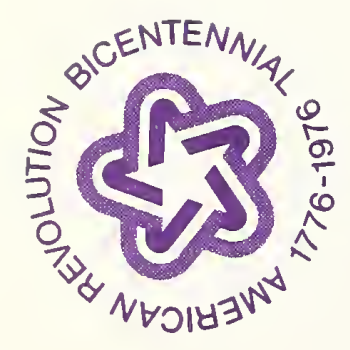

